Volume 4 - Nomor 2 - Februari 2021

Pege (Hal.) : 157 - 167

(c) Universitas Pamulang

website.

JL.Surya Kencana No.1 Pamulang, Tangerang Selatan - Banten Telp. (021) 7412566, Fax (021) 7412491

\title{
Perceived Quality Membentuk Customer Loyalty via Brand Equity pada Pengguna Smartphone Merek Xiaomi di Tangerang Selatan
}

\author{
Rosa Lesmana ${ }^{1}$, Nardi Sunardi ${ }^{2}$, Hastono ${ }^{3}$, Arief Siaha Widodo ${ }^{4}$ \\ ${ }^{1-4}$ University of Pamulang \\ $\frac{{ }^{1} \text { dosen01360@unpam.ac.id, }{ }^{2} \text { dosen01030@unpam.ac.id, }{ }^{3} \text { dosen00034@unpam.ac.id, }}{{ }^{4} \text { dosen01725@unpam.ac.id }}$
}

\begin{abstract}
Abstrak: Penelitian ini mencari tahu apakah Perceived Quality berpengaruh terhadap Customer Loyalty melalui Brand Equity pada pengguna smartphone merek Xiaomi di wilayah Tangerang Selatan. Dengan menggunakan pendekatan penelitian kuantitatif dan metode analisis faktor SEM serta alat uji SPSS Amos 23. Objek analisis adalah konsumen "pengguna smartphone merek Xiaomi" di daerah Tangerang Selatan. Desain penelitian yang digunakan adalah single cross sectional, dengan jumlah sampel sebanyak 150 responden.

Hasil menunjukkan bahwa perceived quality berpengaruh signifikan terhadap brand equity pada smartphone merek Xiaomi di wilayah Tangerang Selatan dengan koefisien regresi sebesar 0.882 dan nilai critical ratio 6.891. Brand equity berpengaruh signifikan terhadap customer loyaty pada smartphone merek Xiaomi di wilayah Tangerang Selatan dengan koefisien regresi sebesar 0.612 dan nilai critical ratio sebesar 5.696. Perceived quality secara langsung tidak berpengaruh signifikan terhadap customer loyalty pada smartphone merek Xiaomi di wilayah Tangerang Selatan dengan koefisien regresi sebesar 0.043 dan nilai critical ratio sebesar 0.385 . Pengaruh tidak langsung perceived quality terhadap customer loyalty $>$ pengaruh secara langsung perceived quality terhadap customer loyalty sebesar $0.482>0.043$, diartikan bahwa brand equity memediasi antara perceived quality dengan customer loyalty pada smartphone merek Xiaomi di wilayah Tangerang Selatan
\end{abstract}

Key word :Perceived Quality: Brand Equity; Customer Loyalty

\begin{abstract}
The objective of the research is to find out whether Perceived Quality affects Customer Loyalty through Brand Equity for Xiaomi brand smartphone users in the South Tangerang area. By using a quantitative research approach and SEM factor analysis methods as well as the SPSS Amos 23 test tool. The object of analysis is consumers of "Xiaomi brand smartphone users" in the South Tangerang area. The research design used was single cross sectional, with a sample size of 150 respondents.

The results show that the perceived quality has a significant effect on brand equity on the Xiaomi brand smartphone in the South Tangerang area with a regression coefficient of 0.882 and a critical ratio value of 6,891. Brand equity has a significant effect on customer loyalty on the Xiaomi brand smartphone in the South Tangerang area with a regression coefficient of 0.612 and a critical ratio value of 5,696. Perceived quality directly has no significant effect on customer loyalty on the Xiaomi brand smartphone in the South Tangerang area with a regression coefficient of 0.043 and a critical ratio value of 0.385 . The indirect effect of perceived quality on customer loyalty> the direct effect of perceived quality on customer loyalty is 0.482> 0.043, which means that brand equity mediates between perceived quality and customer loyalty on the Xiaomi brand smartphone in the South Tangerang area
\end{abstract}

Key word: Perceived Quality; Brand Equity; Customer Loyalty 


\section{A. PENDAHULUAN}

Indonesia sebagai negara yang memiliki populasi terbesar keempat di dunia merupakan pangsa pasar yang strategis bagi pertumbuhan setiap bisnis, termasuk pertumbuhan bisnis telekomunikasi.

Perkembangan pasar yang semakin luas dan dinamis terhadap produk smartphone telah menciptakan persaingan yang ketat dalam pemasaran produk ponsel pintar. Pemasar berlomba lomba untuk menciptakan produk - produk smartphone unggulan dengan berbagai merek dan teknologi yang semakin canggih.

Banyaknya pilihan tersebut membuat permintaan atas smartphone semakin meningkat namun loyalitas terhadap suatu merek smartphone tertentu cenderung menurun (Roza, Erida, \& Shinta, 2015). Tercatat ada lima merek smartphone yang menguasai pasar di Indonesia saat ini.

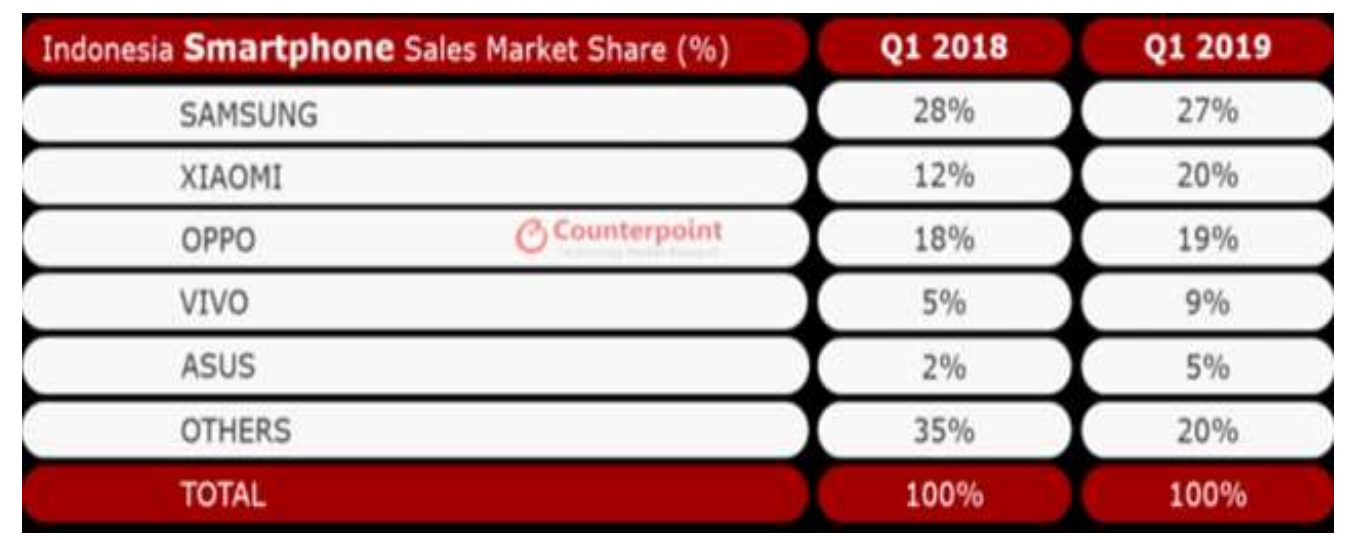

Sumber: kumparan.com

Gambar 1: 5 Merek teratas Smartphone di Indonesia Tahun 2018 dan 2019

Pada gambar 1 dapat kita lihat ada 5 merek teratas yang menguasai pasar smartphone pada tahun 2018 - 2019 di Indonesia, sebagai berikut: Merek Samsung masih pada posisi peringkat pertama dengan pangsa pasar dari $28 \%$ di tahun 2018 terjadi penurunan sebesar $1 \%$ menjadi $27 \%$. Di tahun 2019. Sedangkan posisi kedua dipegang oleh Xiaomi dengan pangsa pasar yang meningkat dari 12\% di tahun 2018 menjadi 20\% di tahun 2019 terjadi penigkatan sebesar 8\%. Diposisi ketiga ditempati oleh Oppo, dengan peningkatan pangsa pasar sebesar 1\% di tahun 2018 sebesar 18\% dan tahun 2019 sebesar $19 \%$. Diposisi keempat ditempati oleh Vivo, dengan peningkatan pangsa pasar sebesar 4\% dari 5\% di tahun 2018 menjadi 9\% di tahun 2019. Diposisi kelima ditempati oleh Asus, yang berhasil menggeser Advan dengan dengan peningkatan pangsa pasar sebesar 3\% dari tahun 2018 sebesar $2 \%$ menjadi 5\% di tahun 2019. Disini dapat kita lihat fenomena yang terjadi dari tahun ke tahun adalah peningkatan pangsa pasar bagi smartphone merek Xiaomi di Indonesia namun tidak mampu menggeser kekuatan merek smartphone Samsung. 


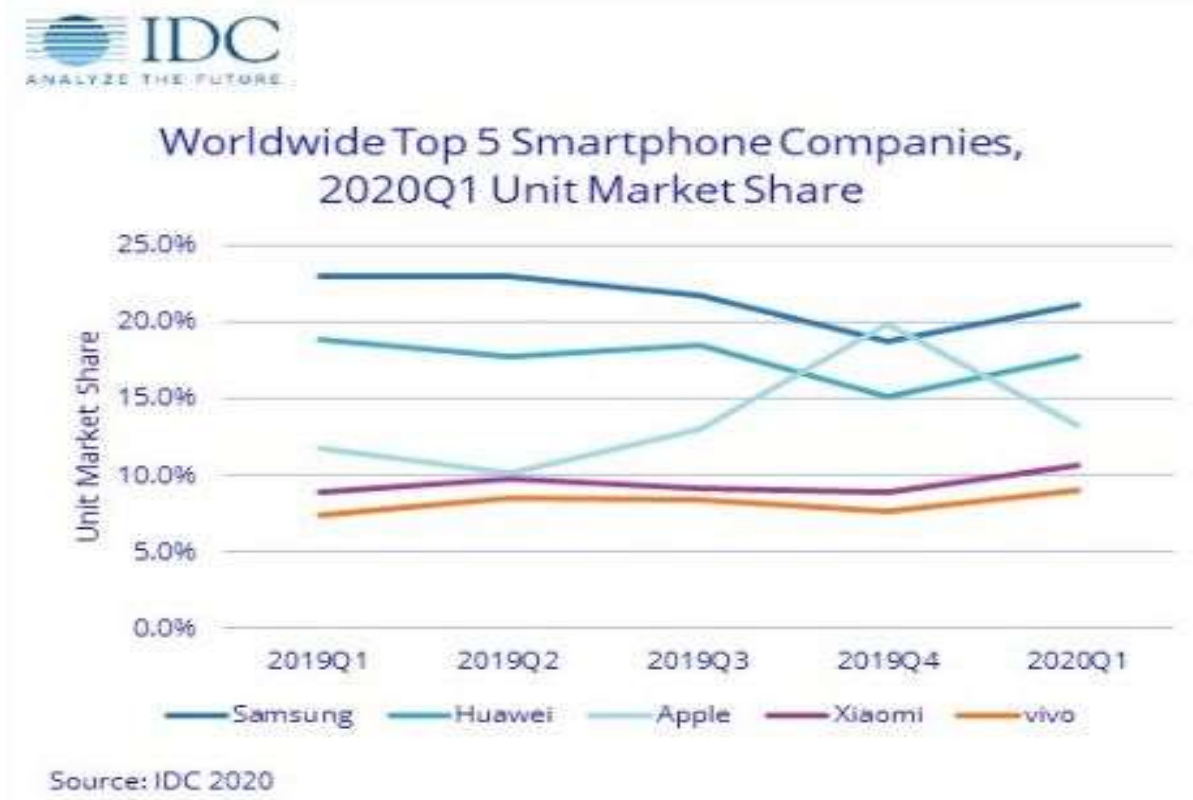

Sumber : IDC

Gambar 2 : 5 Merek teratas pangsa pasar smartphone di dunia tahun 2020

Dari grafik diatas data diambil dari IDC (International Data Corporation) tahun 2020, menunjukkan 5 merek smartphone terbaik dan terlaris di dunia jatuh kepada Samsung. Dengan urutan sebagai berikut : samsung memiliki panngsa pasar dunia sebesar $21.1 \%$, posisi kedua di dunia dipegang oleh huawei dengan pangsa pasar $17.8 \%$, ketiga di dunia di kuasai oleh apple dengan pangsa pasar sebesar $13.3 \%$, sedangkan xiaomi hanya memiliki pangsa pasar sebesar $10.7 \%$ dan vivo memiliki pangsa pasar sebesar $4,8 \%$.

Penelitian berjudul "Perceived Quality dalam Membentuk Customer Loyalty melalui Brand Equity pada Pengguna Smartphone Merek Xiaomi di Tangerang Selatan".

\section{Tujuan Penelitian}

1 Untuk mengetahui pengaruh antara perceived quality (PQ) terhadap Brand Equity (BE) pada pengguna Smartphone Merek Xiaomi di wilayah Tangerang Selatan?

2 Untuk mengetahui pengaruh Brand Equity (BE) terhadap Customer Loyalty (CL) pada pengguna Smartphone Merek Xiaomi di wilayah Tangerang Selatan?

3 Untuk mengetahui pengaruh langsung Perceived Quality (PQ) terhadap Customer Loyalty (CL) pada pengguna Smartphone Merek Xiaomi di wilayah Tangerang Selatan?

4 Untuk mengetahui pengaruh tidak langsung Perceived Quality (PQ) terhadap Customer Loyalty (CL) melalui Brand Equity (BE) 


\section{B. LANDASAN TEOR}

Ekuitas Merek (Brand Equity) menurut Aaker (Aaker, 2005) "adalah seperangkat aset dan liabilitas merek yang berkaitan dengan suatu merek, nama dan simbolnya yang mampu menambah atau mengurangi nilai yang diberikan oleh sebuah produk baik pada perusahaan maupun pada konsumen".

Menurut (Alghofari, Pratiwi, \& Astuti, 2009) dalam penelitiannya menulis bahwa Brand Equity adalah satu set brand asset dan liability yang berhubungan dengan sebuah merek, nama, dan simbol yang disediakan sebuah produk atau servis bagi konsumen.

"Brand Equity mempunyai lima kategori", yaitu:

1. Brand Loyalty (loyalitas merek)

2. Brand Awarness (kesadaran merek)

3. $\quad$ Perceived quality (persepsi kualitas)

4. Brand Associations

5. Other proprietary brand assets (Asset-aset merek lainnya).

Customer Loyalty menurut (Mowen \& Minor, 2001) "mengemukakan bahwa loyalitas dapat didasarkan pada perilaku pembelian aktual produk yang dikaitkan dengan proporsi pembelian". (Oliver, 1999) "mendefinisikan loyalitas merek sebagai suatu komitmen yang mendalam untuk melakukan pembelian ulang produk atau jasa yang menjadi preferensinya secara konsisten pada masa yang akan datang dengan cara membeli ulang merek yang sama meskipun ada pengaruh situasional dan usaha pemasaran yang dapat menimbulkan perilaku peralihan".

\section{METODOLOGIPENELITIAN}

Penelitian adalah penelitian kuantitatif dengan metode analisis faktor, dan SEM serta alat uji SPSS Amos 23. Objek analisis adalah konsumen pengguna smartphone merek Xiaomi di wilayah Tangerang Selatan. Desain penelitian yang digunakan adalah single cross sectional, dengan jumlah sampel sebanyak 150 responden.

Dengan model penelitian sebagai berikut:

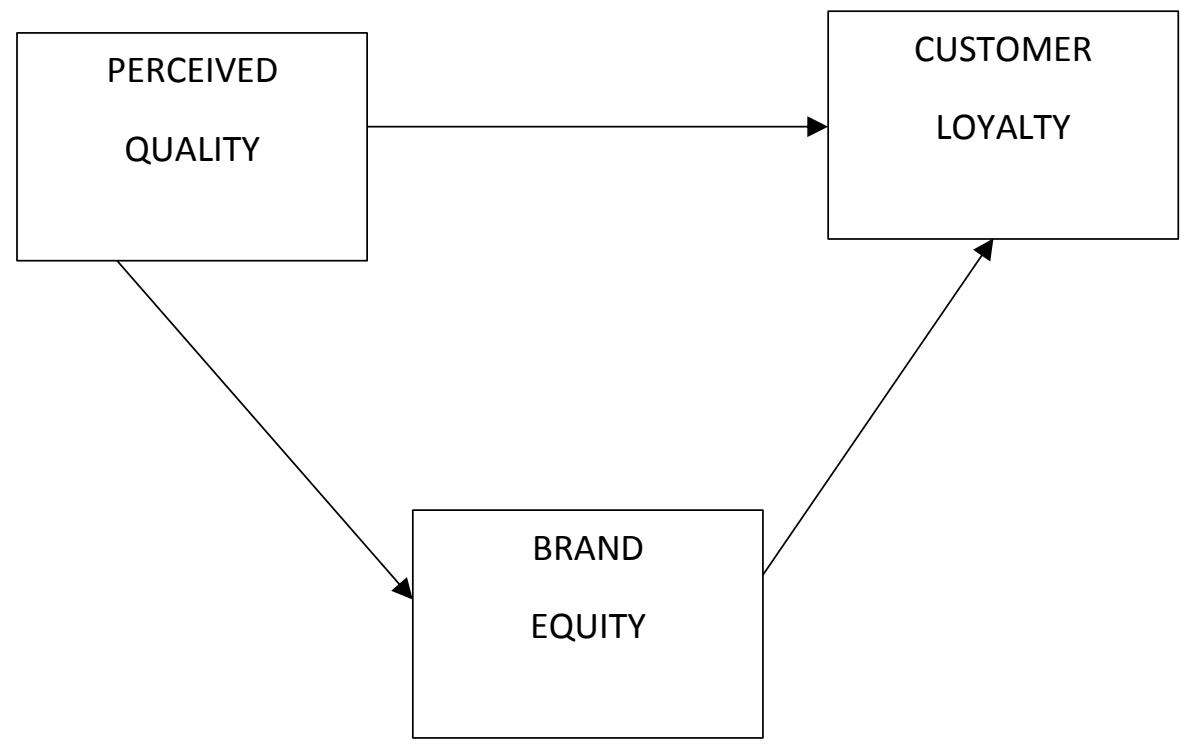

Gambar 3 : Model Penelitian 


\section{Hipotesis:}

1. $\mathrm{H} 1$ = Perceived quality $(\mathrm{PQ})$ berpengaruh positif dan signifikan terhadap Brand Equity (BE) pada pengguna Smartphone Merek Xiaomi di wilayah Tangerang Selatan?

2. $\mathrm{H} 2$ = Brand Equity $(\mathrm{BE})$ berpengaruh positif dan signifikan terhadap Customer Loyalty $(\mathrm{CL})$ pada pengguna Smartphone Merek Xiaomi di wilayah Tangerang Selatan?

3. $\mathrm{H} 3$ = Perceived Quality $(\mathrm{PQ})$ berpengaruh positif dan signifikan terhadap Customer Loyalty (CL) pada pengguna Smartphone Merek Xiaomi di wilayah Tangerang Selatan?

4. $\mathrm{H} 4=$ Perceived Quality (PQ) berpengaruh positif dan signifikan terhadap Customer Loyalty $(\mathrm{CL})$ melalui Brand Equity $(\mathrm{BE})$

\section{HASIL DAN PEMBAHASAN}

Berikut hasil analisi deskriptif dari jawaban responden:

Tabel 1 : Analisis Deskriptif Perceived Quality

\begin{tabular}{|l|l|c|c|}
\hline \multicolumn{2}{|c|}{ Variabel/Instrumen } & $\begin{array}{c}\text { Rata-rata } \\
\text { Skor }\end{array}$ & Kategori \\
\hline \multirow{4}{*}{$\begin{array}{l}\text { Serceived } \\
\text { Quality } \\
\text { kualitas yang baik }\end{array}$} & $\begin{array}{l}\text { Smartphone merek Xiaomi memiliki } \\
\text { kesesuaian harga dengan kualitas }\end{array}$ & 3.98 & Baik \\
\cline { 2 - 4 } & $\begin{array}{l}\text { Smartphone merek Xiaomi memiliki } \\
\text { reputasi yang baik }\end{array}$ & 3.74 & Baik \\
\cline { 2 - 4 } & $\begin{array}{l}\text { Smartphone merek Xiaomi memiliki } \\
\text { manfaat dan nilai yang tinggi }\end{array}$ & 3.71 & Baik \\
\hline \multicolumn{1}{|c|}{ Rata-rata Skor Perceived Quality } & 3.77 & Baik \\
\hline
\end{tabular}

Sumber : Olah data, 2020

Tabel 1menggambarkan bahwa perceived quality smartphone Xiaomi berada pada rata-rata skor sebesar 3.77 masuk pada kategori baik.

Tabel 2 : Analisis Deskriptif Brand Equity

\begin{tabular}{|l|l|c|c|}
\hline \multicolumn{2}{|c|}{ Variabel/Instrumen } & $\begin{array}{c}\text { Rata-rata } \\
\text { Skor }\end{array}$ & Kategori \\
\hline $\begin{array}{l}\text { Brand } \\
\text { Equity }\end{array}$ & $\begin{array}{l}\text { Smartphone merek Xiaomi cocok } \\
\text { dengan pribadi saya }\end{array}$ & 3.31 & Kurang Baik \\
\cline { 2 - 4 } & $\begin{array}{l}\text { Saya merasa bangga menggunakan } \\
\text { Smartphone merek Xiaomi }\end{array}$ & 3.13 & Kurang Baik \\
\cline { 2 - 4 } & $\begin{array}{l}\text { Saya merasa senang menggunakan } \\
\text { Smartphone merek Xiaomi }\end{array}$ & 3.41 & Baik \\
\hline
\end{tabular}




\begin{tabular}{|c|c|c|}
\hline Variabel/Instrumen & $\begin{array}{c}\text { Rata-rata } \\
\text { Skor }\end{array}$ & Kategori \\
\hline Rata-rata Skor Brand Equity & $\mathbf{3 . 2 8}$ & Kurang Baik \\
\hline
\end{tabular}

Sumber : Olah data, 2020

Tabel 2 menginformasik data bahwa brand equity smartphone Xiaomi berada pada rata-rata skor jawaban 3.28 masuk pada kategori kurang baik.

Tabel 3 : Analisis Deskriptif Customer Loyalty

\begin{tabular}{|l|l|c|c|}
\hline \multicolumn{2}{|c|}{ Variabel/Instrumen } & $\begin{array}{c}\text { Rata-rata } \\
\text { Skor }\end{array}$ & Kategori \\
\hline $\begin{array}{l}\text { Customer } \\
\text { Loyalty }\end{array}$ & $\begin{array}{l}\text { Bersedia membayar lebih tinggi } \\
\text { Smartphone merek Xiaomi } \\
\text { dibanding merek lain }\end{array}$ & 2.45 & Tidak Baik \\
\cline { 2 - 4 } & $\begin{array}{l}\text { Berkomitmen untuk tetap } \\
\text { memilih Smartphone merek } \\
\text { Xiaomi dibanding merek lain }\end{array}$ & 2.89 & Kurang Baik \\
\cline { 2 - 4 } & $\begin{array}{l}\text { Tetap setia pada Smartphone } \\
\text { merek Xiaomi }\end{array}$ & 2.95 & Kurang Baik \\
\hline \multicolumn{2}{|l|}{ Rata-rata Skor Customer Loyalty } & $\mathbf{2 . 7 5}$ & Kurang Baik \\
\hline
\end{tabular}

Sumber : Olah data, 2020

Tabel 3 memperlihatkan Customer Loyalty Smartphone Xiaomi berada pada rata-rata skor sebesar 2.75 masuk pada kategori kurang baik.

\section{Confirmatory Factor Analysis}

Tabel 4 : Hasil Uji CFA Models

\begin{tabular}{|c|c|c|c|c|}
\hline Variabel & Pernyataan & Loading & Kriteria & Kesimpulan \\
\hline \multirow[t]{4}{*}{$\begin{array}{l}\text { Perceived } \\
\text { Quality }\end{array}$} & $\begin{array}{l}\text { Smartphone merek } \\
\text { Xiaomi memiliki kualitas } \\
\text { yang baik }\end{array}$ & 0.91 & \multirow{6}{*}{0,30} & Valid \\
\hline & $\begin{array}{l}\text { Smartphone merek } \\
\text { Xiaomi memiliki } \\
\text { kesesuaian harga } \\
\text { dengan kualitas }\end{array}$ & 0,63 & & \\
\hline & $\begin{array}{l}\text { Smartphone merek } \\
\text { Xiaomi memiliki reputasi } \\
\text { yang baik }\end{array}$ & 0.73 & & Valid \\
\hline & $\begin{array}{l}\text { Smartphone merek } \\
\text { Xiaomi memiliki manfaat } \\
\text { dan nilai yang tinggi }\end{array}$ & 0.74 & & Valid \\
\hline \multirow[t]{2}{*}{$\begin{array}{l}\text { Brand } \\
\text { Equity }\end{array}$} & $\begin{array}{l}\text { Smartphone merek } \\
\text { Xiaomi cocok dengan } \\
\text { pribadi saya }\end{array}$ & 0.82 & & Valid \\
\hline & Saya merasa bangga & 0.88 & & Valid \\
\hline
\end{tabular}




\begin{tabular}{|c|c|c|c|c|}
\hline Variabel & Pernyataan & Loading & Kriteria & Kesimpulan \\
\hline & $\begin{array}{l}\text { menggunakan } \\
\text { Smartphone merek } \\
\text { Xiaomi }\end{array}$ & & & \\
\hline & $\begin{array}{l}\text { Saya merasa senang } \\
\text { menggunakan } \\
\text { Smartphone merek } \\
\text { Xiaomi }\end{array}$ & 0.82 & & Valid \\
\hline \multirow[t]{3}{*}{$\begin{array}{l}\text { Customer } \\
\text { Loyalty }\end{array}$} & $\begin{array}{l}\text { Bersedia membayar lebih } \\
\text { tinggi untuk Smartphone } \\
\text { merek Xiaomi dibanding } \\
\text { merek lain }\end{array}$ & 0.66 & & Valid \\
\hline & $\begin{array}{l}\text { Berkomitmen untuk tetap } \\
\text { memilih Smartphone } \\
\text { merek Xiaomi dibanding } \\
\text { merek lain }\end{array}$ & 0.92 & & Valid \\
\hline & $\begin{array}{l}\text { Tetap setia pada } \\
\text { Smartphone merek } \\
\text { Xiaomi }\end{array}$ & 0.93 & & Valid \\
\hline
\end{tabular}

Sumber: Hasil Olah Data Amos 23, 2020

Tabel 4 memberikan informasi bahwa semua indikator dalam penelitian ini memilikin kriteria valid dengan nilai standard loading factor $>0,3$

Tabel 5 : Evaluasi Nilai AVE dan CR

\begin{tabular}{|l|l|c|c|c|c|c|}
\hline No & Variabel & AVE & Kriteria & CR & Kriteria & Kesimpulan \\
\hline 1 & $\begin{array}{l}\text { Perceived } \\
\text { Quality }\end{array}$ & 0.59 & & 0.85 & & Valid dan Reliabel \\
\hline 2 & Brand Equity & 0.62 & \multirow{2}{*}{0,50} & 0.83 & 0,60 & Valid dan Reliabel \\
\cline { 1 - 2 } & $\begin{array}{l}\text { Customer } \\
n\end{array}$ & 0.72 & & 0.92 & & Valid dan Reliabel \\
\hline
\end{tabular}

Tabel 5 menjelaskan bahwa keempat variabel memiliki nilai Average Varians Extract $($ AVE) $>0,50$ dan nilai Construct Reliability $(\mathrm{CR})>0,60$ maka dapat disimpulkan bahwa semua variabel tersebut Valid dan Reliabel.

\section{Goodness of Fit}

Tabel 6 : Goodness of Fit

\begin{tabular}{|l|c|c|c|}
\hline \multicolumn{1}{|c|}{ Kreteria } & $\begin{array}{c}\text { Hasil Model } \\
\text { ini }\end{array}$ & Nilai Kritis & $\begin{array}{c}\text { Evaluasi } \\
\text { Model }\end{array}$ \\
\hline $\begin{array}{l}\text { Chi-Square } X^{2} \\
\text { CMIN }\end{array}$ & 31.982 & $\begin{array}{l}\text { Besar, } X^{2} \text { dengan } \\
\text { df=32 }\end{array}$ & Baik \\
\hline Probability (P) & 0.468 & $\geq 0.05$ & Baik \\
\hline $\begin{array}{l}X^{2} \text { Relatif } \\
\text { (CMIN/DF) }\end{array}$ & 0.999 & $\leq 2.0$ & Baik \\
\hline GFI & 0.958 & $\geq 0.90$ & baik \\
\hline AGFI & 0.929 & $\geq 0.90$ & baik \\
\hline TLI & 1.000 & $\geq 0.95$ & baik \\
\hline CFI & 1.000 & $\geq 0.95$ & baik \\
\hline RMSEA & 0.000 & $\leq 0.08$ & baik \\
\hline
\end{tabular}


Tabel 6 diatas menggambarkan bahwa "Confirmatory Factor Analysis" dalam mengukur model penelitian ini adalah baik, dimana nilai GFI, AGFI lebih tinggi dari tingkat yang disarankan yaitu $\geq 0.9$; nilai TLI dan CFI lebih tinggi dari tingkat yang disarankan yaitu $\geq 0,95$; nilai RMSEA $0,00 \leq 0,08$ termasuk kriteria yang lainnya.

\section{Persamaan SEM dengan menggunakan program Amos 23}

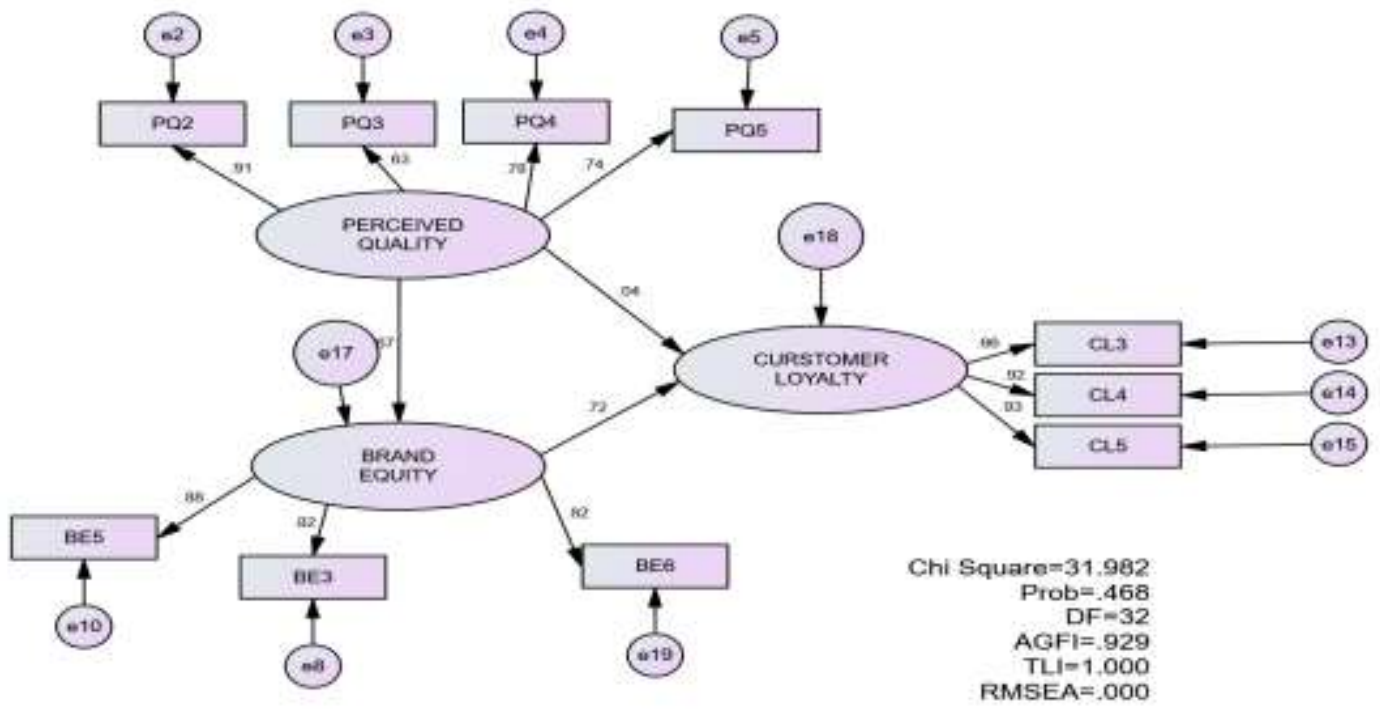

Gambar 5. 2: SEM Standardized Model

Tabel 7 : Uji Statistik Pengaruh Langsung Model Regression Weights

\begin{tabular}{|l|c|c|c|c|c|}
\hline \multicolumn{1}{|c|}{$\begin{array}{c}\text { Regression } \\
\text { Weight }\end{array}$} & Estimate & $\begin{array}{c}\text { Standardise } \\
\text { d Estimate }\end{array}$ & C.R & P & Hasil \\
\hline $\begin{array}{l}\text { Brand Equity <--- } \\
\text { Perceived Quality }\end{array}$ & .882 & .128 & 6.891 & $* * *$ & Signifikan \\
\hline $\begin{array}{l}\text { Customer Loyalty } \\
<--- \text { Brand Equity }\end{array}$ & .612 & .108 & 5.696 & $* * *$ & Signifikan \\
\hline $\begin{array}{l}\text { Customer Loyalty } \\
\text { <--- Perceived } \\
\text { Quality }\end{array}$ & .043 & .110 & .385 & .700 & $\begin{array}{c}\text { Tidak } \\
\text { Signifikan }\end{array}$ \\
\hline
\end{tabular}

Sumber : Hasil Pengolahan Data Amos 23, 2020

Uji Regression Weight pada tabel 7 diatas menunjukkan pengaruh secara langsung pada hipotesis 1 berpengaruh signifikan dengan nilai C.R $6.891>1,96$ dan Hipotesis 2 berpengaruh signifikan dengan nilai C.R $5.696>1,96$, sedangkan hipotesis 3 tidak berpengaruh signifikan dengan nilai C.R $0,385<1,96$.

Tabel 8 : Uji Statistik Pengaruh Tidak Langsung Model Regression Weights

\begin{tabular}{|l|c|c|c|c|}
\hline \multicolumn{1}{|c|}{$\begin{array}{c}\text { Regression } \\
\text { Weight }\end{array}$} & $\begin{array}{c}\text { Pengaruh } \\
\text { Tidak } \\
\text { Langsung }\end{array}$ & $\begin{array}{c}\text { Pengaruh } \\
\text { Langsung }\end{array}$ & Kriteria & Hasil \\
\hline $\begin{array}{l}\text { Customer Loyalty } \\
\text { <-- Perceived } \\
\text { Quality }\end{array}$ & 0.482 & 0.043 & $\begin{array}{c}\text { Pengaruh Tidak } \\
\text { Langsung > Pengaruh } \\
\text { Langsung }\end{array}$ & Memediasi \\
\hline
\end{tabular}

Sumber : Hasil Pengolahan Data Amos 23, 2020 
Tabel 8 menunjukkan bahwa pengaruh tidak langsung perceived quality terhadap customer loyalty melalui brand equity lebih besar dari pada pengaruh langsung perceived quality terhadap customer loyalty hal ini berarti bahwa brand equity memediasi antara perceived quality dengan customer loyaty.

\section{E. KESIMPULAN DAN SARAN}

\section{Kesimpulan}

1. Perceived quality berpengaruh signifikan terhadap brand equity pada smartphone merek Xiaomi di wilayah Tangerang Selatan dengan koefisien regresi sebesar 0.882 dan nilai critical ratio 6.891 .

2. Brand equity berpengaruh signifikan terhadap customer loyaty pada smartphone merek Xiaomi di wilayah Tangerang Selatan dengan koefisien regresi sebesar 0.612 dan nilai critical ratio sebesar 5.696

3. Perceived quality secara langsung tidak berpengaruh signifikan terhadap customer loyalty pada smartphone merek Xiaomi di wilayah Tangerang Selatan dengan koefisien regresi sebesar 0.043 dan nilai critical ratio sebesar 0.385 .

4. Pengaruh tidak langsung perceived quality terhadap berand equity $>$ pengaruh secara langsung perceived quality terhadap customer loyalty sebesar $0.482>0.043$, sehingga dapat disimpulkan bahwa brand equity memediasi antara perceived quality dengan customer loyalty pada smartphone merek Xiaomi di wilayah Tangerang Selatan.

\section{Saran}

1. Berdasarkan jawaban responden yang bernilai kurang baik terhadap pernyataaan "smartphone xiaomi cocok dengan pribadi saya" dan pernyataan "aku bangga menggunakan smartphone merek xiaomi" maka disarankan agar dapat meningkatkan brand equity smartphone merek xiaomi.

2. Berdasarkan jawaban responden yang kurang baik terhadap pernyataan "aku bersedia membayar lebih mahal untuk smartphone xiaomi" maka disarankan untuk meningkatkan customer loyalty melalui peningkatan kehandalan, kualitas, teknologi dan fitur.

3. Brand equity terbukti secara statistik berperan dalam memediasi antara variabel perceived quality dengan customer loyalty. Dapat disimpulkan bahwa brand equity smartphones merek Xiaomi akan terbentuk secara baik apabila perceived quality dapat berpengaruh terhadap customer loyalty. Sehingga disarankan kepada smartphones merek Xiaomi wilayah Tangerang Selatan untuk mempertahankan dan meningkatkan perceived quality yang sudah baik saat ini. 


\section{DAFTAR PUSTAKA}

Aaker, D. A. (2005). Strategic Market Management. New York,: John Wiley \& Son.

Alghofari, A. K., Pratiwi, I., \& Astuti, Y. P. (2009). Analisis Pengruh Brand Equity Terhadap Pembentukan Customer Loyalty Pada Jenis Merek Pasta Gigi. Simposium Nasional RAPI VIII 2009, 1-58.

Alvedi, M. (2017). Effect of Brand factors on customer loyalty with the mediating role of brand equity . International Academic Journal of Accounting and Financial Management, 36-46.

Chaudhuri, A., \& Holbrokk, M. B. (2001). The Chain of Effects from Brand Trust and Brand Affect to Brand Performance : The Role of Brand Loyalty. Journal of Marketing. Volume 65. Number 2, 81-93.

Chen, X., Huang, Q., \& Davidson, R. M. (2017). The role of website quality and social capital in building buyers'loyalty. International Journal of Information Management, 1563 - 1574.

Gil, R. B., Andre's, E. F., \& Salinas, M. (2007). Family as a source of consumer-based brand equity. Journal of Product \& Brand Management, 188-199.

Lesmana, R., Widodo, A. S., \& Sunardi, N. (2020). The Formation of Customer Loyalty From Brand Awareness and Perceived Quality through Brand Equity of Xiaomi Smartphone Users in South Tangerang. Jurnal Pemasaran Kompetitif, 4(1), 1-12.

Lesmana, R., Habiyah, W., \& Nabila, N. I. (2020). Peran Kepuasan Wisatawan Terhadap Loyalitas Wisatawan Pada Objek Wisata Kepulauan Seribu Jakarta. JIMF (Jurnal IImiah Manajemen Forkamma), 3(2).

Malhotra, N. K. (2007). Marketing Research: an Applied Orientation. 5th edition. New Jersey: Pearson Education.

Maulidina, R., \& Ariyanti S, M. (Vol.3, No.2 Agustus 2016). Analisis Ekuitas Merek Smartphone Apple dan Samsung Pada Konsumen Muda di Indonesia. eProceeding of Management, 1113 - 1119.

Meizan, I. M., \& Zuliestiana, A. D. (2017 ). Pengaruh Brand Equity Terhadap Customer Loyalty (Studi pada PT JNE Cabang Kantor Perwakilan Bandung). e-Proceeding of Management, 2290 - 2295.

Mowen, J. C., \& Minor, M. (2001). Consumer Behavior: A Framework. New Jersey 67458, Prentice Hall Upper Saddle River: Pearson Education.

Oliver, R. L. (1999). Whence Consumer Loyalty. Journal of Marketing, 33 - 44.

Roza, S., Erida, E., \& Shinta, S. (2015). The influence of Brand on Customer Loyalty of Smartphone Samsung Andorid Basis. Digest Marketing Vol. 1 No.1 Juli, 2015, 58 64.

Sunardi, N., \& Lesmana, R. (2020). Konsep Icepower (Wiramadu) sebagai Solusi Wirausaha menuju Desa Sejahtra Mandiri (DMS) pada Masa Pandemi Covid19. JIMF (Jurnal IImiah Manajemen Forkamma), 4(1). 
Shihab, M. S., \& Sukendar, A. (2009). Pengaruh Brand Trust dan Brand Equity Terhadap Loyalitas konsumen Studi Kasus pada Produk Tes Widal Merek Remel. Jurnal IImiah Manajemen Bisnis Dan Terapan, 83 - 96.

Simon, P., \& Tjokrosaputro, M. (2018). Pengaruh Brand Awareness, Perceived Quality dan Brand Trust. Jurnal Manajemen Bisnis Dan Kewirausahaan, 14 - 23.

Suyadi, M. I., \& Fanani, D. (2014). Pengaruh Brand Awarness, Brand Association, Perceived Quality dan Brand Loyalty Terhadap Brand EquityTY. Jurnal Administrasi Bisnis (JAB), 1-5. 